\title{
PERANCANGAN SISTEM INFORMASI PENJUALAN, PEMBELIAN, DAN INVENTORI PADA CV BAMBI
}

\author{
Sugiarto Hartono \\ Computerized Accounting Department, School of Information Systems, Binus University \\ Jl. K.H. Syahdan No. 9, Palmerah, Jakarta Barat 11480 \\ shartono@binus.edu
}

\begin{abstract}
CV Bambi considers to use IS and IT to get competitive advantage. Thus, CV Bambi needs a system that utilizes IT and records all business transactions, especially in sales, purchasing, and inventory processes so that data redundancy will be minimal. This research creates information system design of sales, purchasing, and inventory processes as well as reports that can be used by the management. Methodology used in this paper is unified process with object-oriented approach. The result is an information system design that can solve problems in data searching since all the data have been stored in a database. When sales or purchasing transaction occurs, the stock in inventory system will be automatically updated. This system will make easy the manager to read reports by using reporting feature.
\end{abstract}

Keywords: system design, sales system, purchasing system, inventory system

\begin{abstract}
ABSTRAK
CV Bambi sebagai perusahaan yang bergerak dalam bidang penjualan makanan ringan mulai menyadari bahwa penerapan SI dan TI sangat penting dalam pengembangan bisnisnya. Oleh karena itu, CV Bambi membutuhkan sebuah sistem yang memanfaatkan teknologi informasi yang mencatat seluruh transaksi bisnis yang berkaitan dengan sistem informasi penjualan, pembelian, dan inventori dalam sebuah database. Tujuannya agar data mudah dicari oleh unit yang berbeda dan redudansi data akan terminimalisasi. Penelitian ini dilakukan untuk membuat sebuah desain sistem informasi dari proses bisnis penjualan, pembelian, dan inventori yang pada akhirnya akan menghasilkan laporan yang dapat digunakan oleh pihak manajemen. Perancangan menggunakan metode unified process dengan pendekatan object oriented. Hasil dari penelitian ini adalah sebuah rancangan sistem informasi yang dapat mengatasi masalah dalam pencarian data pada proses penjualan, pembelian dan inventori karena semua data telah tersimpan dalam sebuah database. Dengan adanya sistem ini, seluruh data akan tersimpan dalam database dan terbarukan secara real time. Setiap terjadi transaksi penjualan, stok di sistem inventori akan langsung berkurang. Demikian halnya setiap terjadi pembelian barang, stok di inventori akan otomatis bertambah. Selain itu, sistem ini juga memudahkan manajer untuk mendapatkan laporan penjualan, pembelian, dan inventori melalui fitur laporan.
\end{abstract}

Kata kunci: perancangan sistem, sistem penjualan, sistem pembelian, sistem inventori 


\section{PENDAHULUAN}

Perkembangan dunia bisnis terjadi sangat cepat. Seiring waktu, penggunaan Sistem Informasi (SI) dan Teknologi Informasi (TI) dalam pengembangan bisnis menjadi salah satu faktor utama untuk meningkatkan kualitas kinerja perusahaan dalam menjalankan rutinitas proses bisnis. Dengan semakin banyaknya perusahaan yang berlomba-lomba untuk mengimplementasikan TI dalam perusahaan mereka, kebutuhan SI dan TI ikut berkembang pesat.

Sistem informasi harus dapat menyediakan informasi untuk orang yang tepat dalam waktu yang tepat serta dalam format dan jumlah yang tepat dan sesuai dengan kebutuhan penerima informasi (Rainer \& Cegielski, 2011:10). Sistem informasi akan memberikan manfaat bagi user, sistem, organisasi, dan level strategis di dalam perusahaan (Peterson \& Kim, 2000:29). Berdasarkan fungsinya, sistem informasi dapat diklasifikasikan dalam beberapa jenis, yaitu: transaction processing systems, management information system, executive information systems, decision support systems, communication support systems, dan office support systems (Whitten \& Bentley, 2007:6).

Sebuah perusahaan harus memiliki transaction processing system yang baik sebelum dapat mengimplementasikan jenis sistem informasi lainnya. Transaction Processing Systems adalah sistem informasi yang menangkap dan merekam informasi transaksi yang mempengaruhi organisasi, misalnya transaksi order, pembayaran, dan sebagainya (Whitten \& Bentley, 2007:6). Scope transaction processing system yang dibahas dalam penulisan ini adalah sistem penjualan, pembelian, dan inventori. Ketiga sistem tersebut merupakan sistem utama dari setiap perusahaan yang bergerak dalam bidang trading untuk dapat mengoperasikan proses bisnisnya.

Sistem penjualan, pembelian, dan inventori perusahaan yang didukung dengan penggunaan SI dan TI secara maksimal dapat meningkatkan keunggulan secara kualitatif dan kuantitatif. Dilihat dari segi kualitatif, penggunaan SI dan TI dapat meningkatkan efektifitas proses bisnis perusahaan dan meningkatkan kepuasan pelanggan. Dan dilihat dari segi kuantitatif, penggunaan SI dan TI dapat meningkatkan keuntungan ekonomi bagi perusahaan tersebut. Desain sistem informasi yang efektif harus dapat digunakan dan memberikan pengaruh positif bagi kepentingan organisasi (Markus, Majchrzak, \& Gasser, 2003:179).

Objek penelitian yang digunakan adalah CV Bambi. Perusahaan ini bergerak dalam bidang penjualan Food \& Beverages dengan spesialisasi penjualan makanan ringan (snack). Perusahaan ini menganggap bahwa penerapan SI dan TI sangat penting dalam pengembangan bisnis. Namun perusahaan belum menerapkan teknologi informasi ke dalam setiap detail proses bisnisnya. Oleh karena itu, CV Bambi membutuhkan sebuah sistem yang memanfaatkan teknologi informasi yang mencatat seluruh transaksi bisnis yang berkaitan dengan sistem informasi penjualan, pembelian, dan inventori dalam sebuah database sehingga data akan mudah dicari oleh unit yang berbeda. Selain itu, redudansi data akan terminimalisasi. Tujuan dari penelitian ini adalah membuat sebuah desain sistem informasi dari proses bisnis penjualan, pembelian, dan inventori pada CV Bambi, di mana sistem tersebut akan menghasilkan laporan yang dapat digunakan oleh pihak manajemen untuk keperluan strategis.

\section{METODE}

Metode yang digunakan dalam penelitian ini adalah: (1) observasi, yaitu pengamatan dan penelitian pada CV Bambi untuk mendapatkan data dan informasi yang dibutuhkan untuk merancang 
sistem informasi; (2) wawancara, yaitu sesi tanya jawab kepada pihak CV Bambi yang terkait untuk mengetahui proses bisnis yang berjalan serta untuk mengidentifikasi kebutuhan user; (3) analisis sistem pada data-data yang didapat dengan menggunakan metode unified process berorientasi objek.

Unified Process merupakan salah satu metodologi untuk melakukan problem solving dan membutuhkan adanya peran serta partisipasi seluruh stakeholder (Forster \& Brocco, 2008). Stakeholder dalam hal ini adalah pihak pengembang sistem dan pihak perusahaan CV Bambi. Keseluruhan stakeholder tersebut melakukan brainstorming untuk menganalisis sistem yang akan dikembangkan. Analisis sistem dalam penelitian ini menggunakan pendekatan Object-Oriented, di mana untuk penggambaran model analisis menggunakan notasi grafis UML.

Selanjutnya adalah perancangan sistem sesuai dengan analisis yang telah dilakukan. Perancangan sistem ini menggunakan perancangan metode berorientasi objek. Tahapan desain sistem yang dilakukan yaitu: (1) desain support services architecture dan deployment environment; (2) desain software architecture; (3) desain usecase realization; (4) desain user interface; (5) desain system security and control (Satzinger, Jackson, \& Burd, 2012:162).

\section{HASIL DAN PEMBAHASAN}

Saat ini sistem penjualan pada CV Bambi masih menggunakan sistem manual. Di bawah ini adalah proses bisnis yang diusulkan setelah menggunakan sistem komputerisasi:

Pemilik melakukan perekrutan agen yang sebelumnya melakukan survei terlebih dahulu. Setelah menemukan agen, pemilik akan mencatat data agen serta agen memberikan surat jaminan. Kemudian, pemilik akan memasukkan data agen dan surat jaminan ke dalam sistem.

Bagian administrasi menerima pemesanan dari agen melalui SMS yang berisi nama dan jumlah snack. Pemesanan tersebut akan dimasukkan oleh bagian administrasi ke dalam nota pemesanan dengan catatan agen harus membayar down payment minimal 15\% dari total harga. Setelah agen membayar down payment maka bukti pembayaran agen (DP) akan dibuat oleh bagian keuangan. Setelah itu bagian administrasi akan membuat surat keluar snack yang berisi nama dan jumlah snack yang ditujukan ke bagian gudang.

Setelah menerima surat keluar snack dari bagian administrasi, bagian gudang akan mengecek ketersediaan jumlah snack yang ada. Apabila ketersediaan snack digudang mencukupi, bagian gudang akan membuat surat jalan dan bagian keuangan akan membuat faktur tagihan. Apabila tidak mencukupi, bagian gudang akan membuat surat permintaan snack yang berisi nama snack yang ketersediaannya melewati batas minimum ke bagian administrasi. Bagian keuangan bertugas membuat faktur tagihan yang akan diberikan ke agen. Faktur tagihan tersebut berisi total tagihan yang belum dibayarkan oleh agen. Surat jalan yang dibuat oleh bagian gudang akan diserahkan ke bagian pengiriman beserta faktur tagihan yang telah dibuat oleh bagian keuangan.

Bagian keuangan menerima bukti sisa pembayaran melalui faks yang dikirimkan oleh agen. Apabila agen telah melakukan pelunasan pembayaran, bagian keuangan akan membuat bukti pembayaran agen (lunas) dan akan dikirimkan kembali ke agen melalui faks. Setelah menerima surat permintaan snack dari bagian gudang, Bagian administrasi akan melakukan pemesanan snack ke supplier dengan cara mengirimkan SMS kepada supplier. Pemesanan tersebut akan dicatat dan disimpan ke purchase order. Setelah bagian administrasi melakukan pemesanan, supplier akan mengirimkan snack yang dipesan. 
Barang yang telah dikirim oleh supplier akan diterima oleh bagian gudang dan akan dibuat surat penerimaan barang. Setelah barang diterima, bagian keuangan akan melakukan pembayaran down payment sebesar $15 \%$ dari total harga kepada supplier dan akan dimasukkan ke dalam bukti pembayaran supplier (DP). Dalam jangka waktu tertentu bagian keuangan akan melakukan pelunasan pembayaran kepada supplier dan disimpan ke dalam bukti pembayaran supplier (lunas).

Seluruh proses di atas dirangkum pada rich picture di bawah ini (Gambar 1).

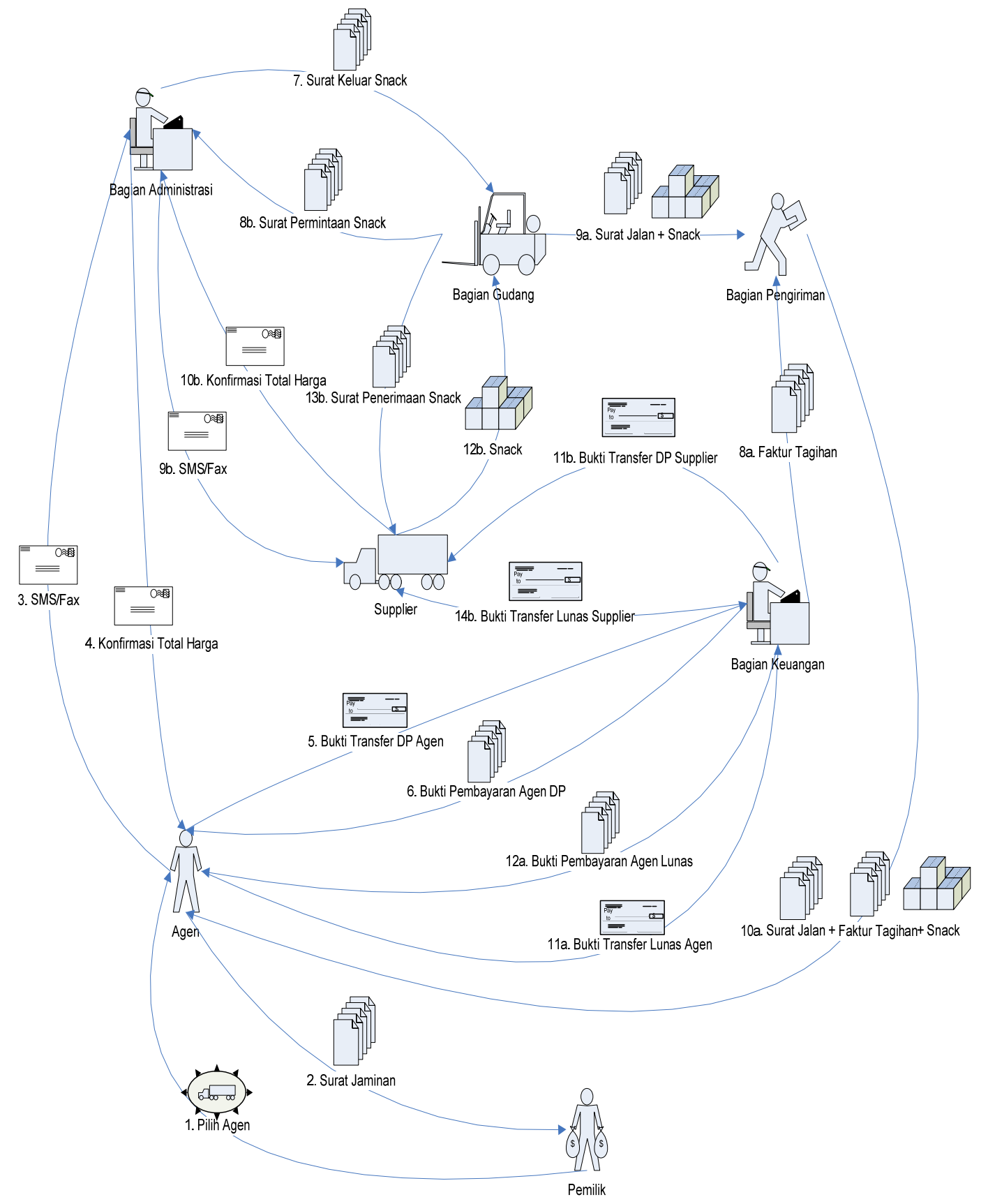

Gambar 1 Proses bisnis penjualan, pembelian, dan inventori yang diusulkan.

Functional requirement digambarkan menggunakan usecase diagram seperti berikut ini (Gambar 2): 


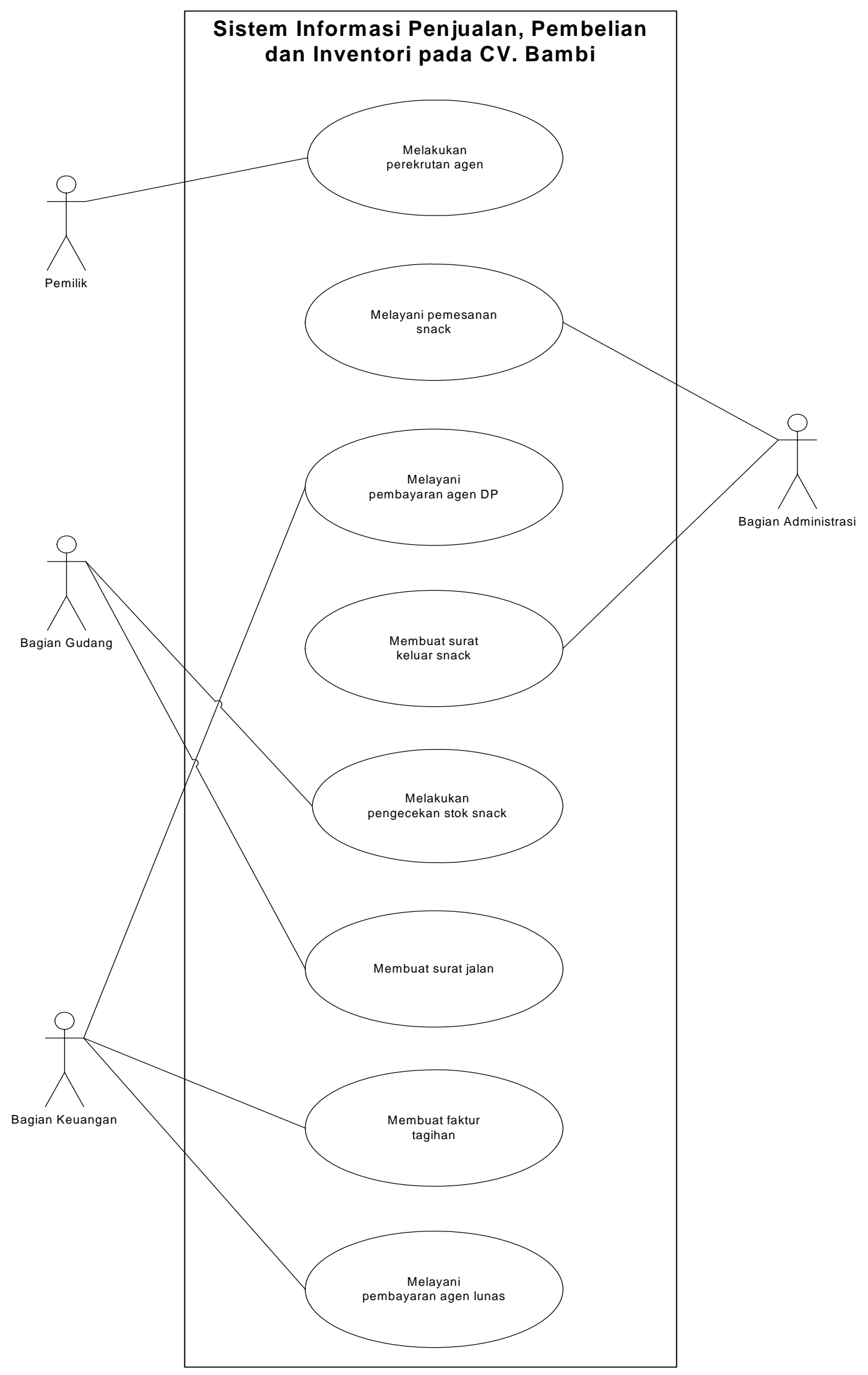

Gambar 2 Usecase diagram 


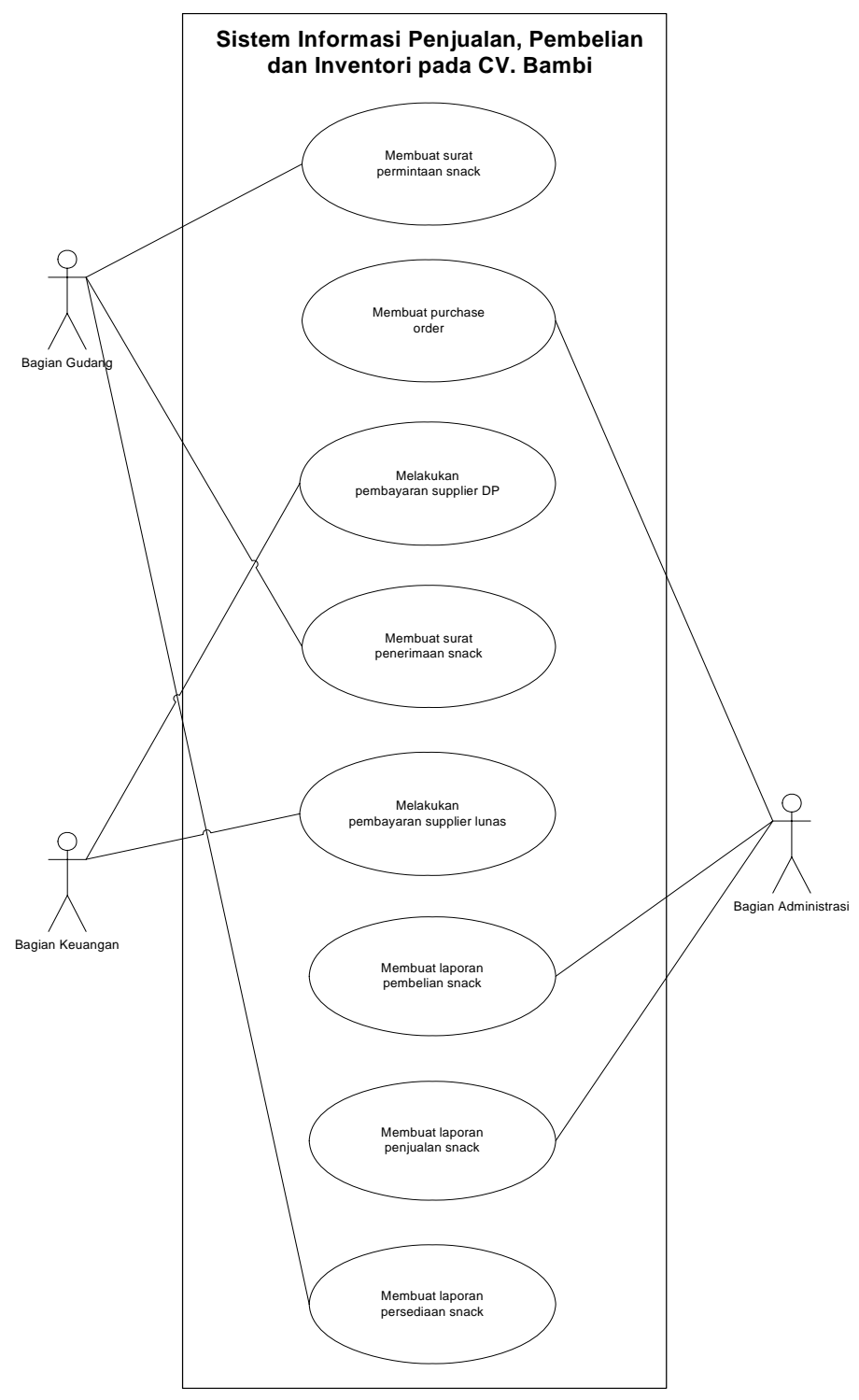

Gambar 2 Usecase Diagram (Lanjutan)

CV Bambi menggunakan deployment architecture (Gambar 3) dengan tipe multitier architecture yang memungkinkan kegiatan computing terjadi di beberapa komputer. Hal tersebut dapat dilihat dari sistem yang berjalan di CV Bambi cukup banyak, meliputi proses pembayaran ke agen dan supplier, update stok snack. CV Bambi menjalankan semua sistem menggunakan tipe multicomputer architecture, dengan pembagian beban melalui spesialisasi fungsi. Oleh karena itu, tiap komputer yang digunakan memiliki spesifikasi yang berbeda yang disesuaikan berdasarkan fungsi dan peran nya masing-masing. Walaupun setiap bagian memiliki fungsi dan peran yang berbeda, semua bagian tetap saling terhubung satu sama lain. Makad adri itu ehingga suatu pekerjaan dapat direspon dengan cepat oleh bagian lain yang akan melanjutkan pekerjaan tersebut. Hal ini dapat terjadi karena setiap bagian sudah tersambung oleh server. CV Bambi menempatkan semua sumber penghitungan pada tempat yang terpusat, karena CV Bambi tidak memilik cabang di tempat lainnya, sehingga tidak memerlukan jaringan komputer untuk menghubungkan. 


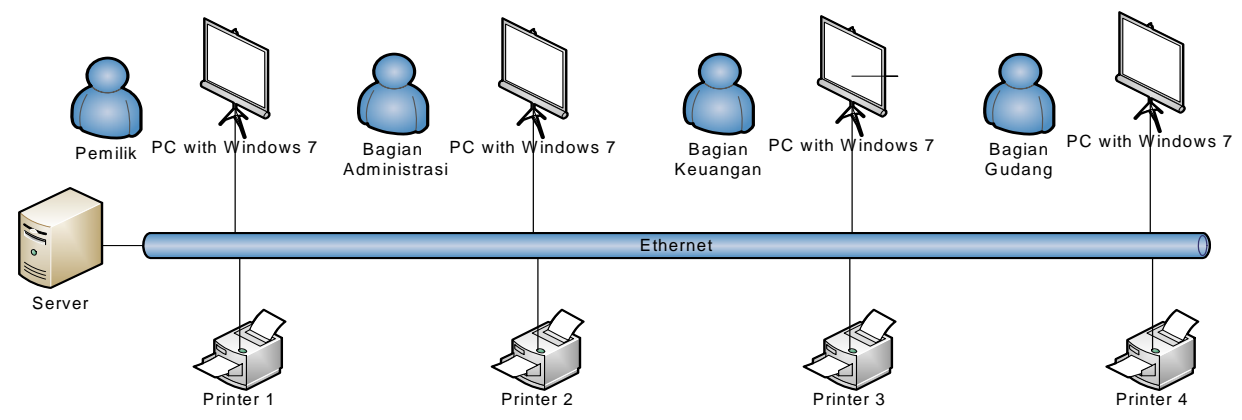

Gambar 3 Deployment environment

CV Bambi menggunakan two tier pada software architecture, karena setiap bagian menggunakan aplikasi yang sama pada setiap komputernya, dan dapat mengakses ke database yang sama karena memiliki server yang sama dan saling terhubung satu sama lain. Di bawah ini adalah class diagram yang dirancang (Gambar 4). Rancangan User Interface yang diusulkan sebagai berikut:

Untuk membuat nota pemesanan (Gambar 5), Bagian administrasi harus memilih button Create New terlebih dahulu. Lalu dimulai dari pemilihan agen yang memesan. Ketika textbox ID agen diklik, akan muncul form yang menampilkan data agen. Berikutnya, bagian administrasi memilih snack yang dipesan oleh agen, dan list snack yang dipesan oleh agen akan ditampilkan di datagrid detil nota pemesanan. Jika terdapat kesalahan dalam penginputan data snack, bagian administrasi bisa menggunakan button reset untuk menghapus data-data yg ada di datagrid, lalu bagian administrasi bisa memasukkan ulang snack yang ingin dipesan. Setelah selesai, bagian administrasi dapat memilih button Save and Print untuk menyimpan dan mencetak Nota Pemesanan yang dibuat. Button Cancel digunakan untuk menutup form nota pemesanan.

Untuk membuat surat keluar snack yang baru (Gambar 6), Bagian administrasi harus memilih button Create New terlebih dahulu. Dimulai dari pemilihan nota pemesanan. Ketika textbox KD Nota Pemesanan terisi, lalu nama agen akan terisi secara otomatis. Berikutnya, bagian administrasi bisa melihat list snack yang sudah dipesan agen di datagrid. Setelah selesai, bagian administrasi dapat memilih button Save and Print, maka surat keluar snack akan tersimpan dan muncul Print Preview. Button cancel digunakan untuk menutup form surat keluar snack.

Untuk membuat purchase order (Gambar 7), Bagian administrasi harus memilih button Create New terlebih dahulu yang baru. Berikutnya, bagian administrasi memilih supplier yang akan menyuplai snack, dan memilih kd surat permintaan snack. List snack yang dipesan pun akan ditampilkan di datagrid detil surat permintaan snack. Setelah selesai, bagian administrasi dapat memilih button Save and Print, untuk menyimpan dan mencetak purchase order. Button cancel digunakan untuk menutup form purchase order.

Untuk membuat laporan penjualan (Gambar 8), Bagian Adminstrasi pertama kali harus memilih periode laporan penjualan. Bagian administrasi bisa memilih laporan penjualan ingin ditampilkan berdasarkan nama agen atau nama snack. Setelah itu, bagian administrasi harus memilih button OK untuk menampilkan data transaksi penjualan selama periode yang telah ditentukan. Lalu, bagian administrasi bisa memilih untuk mencetak dengan memilih button Print. 


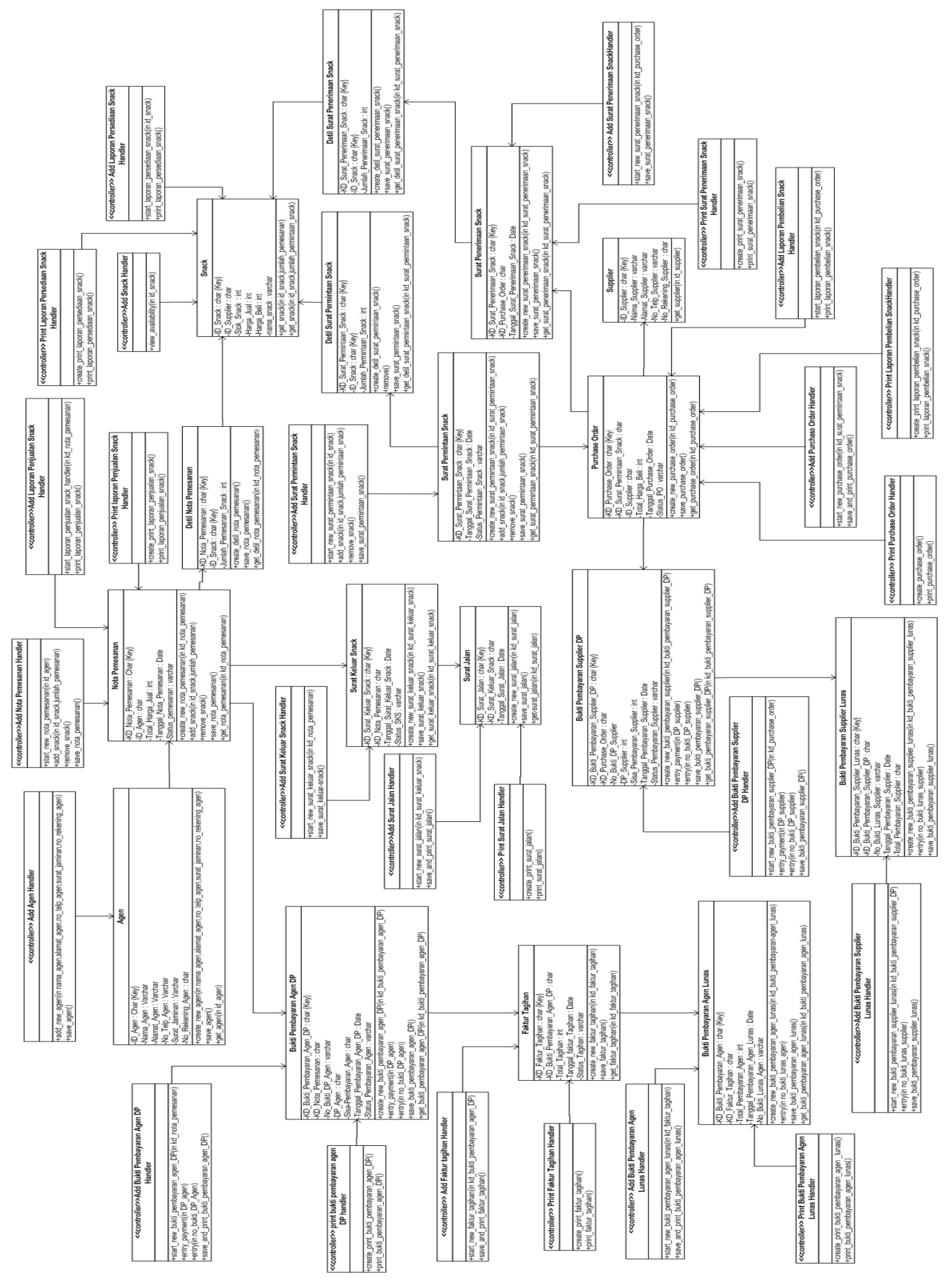

Gambar 4 Updated Design Class Diagram 


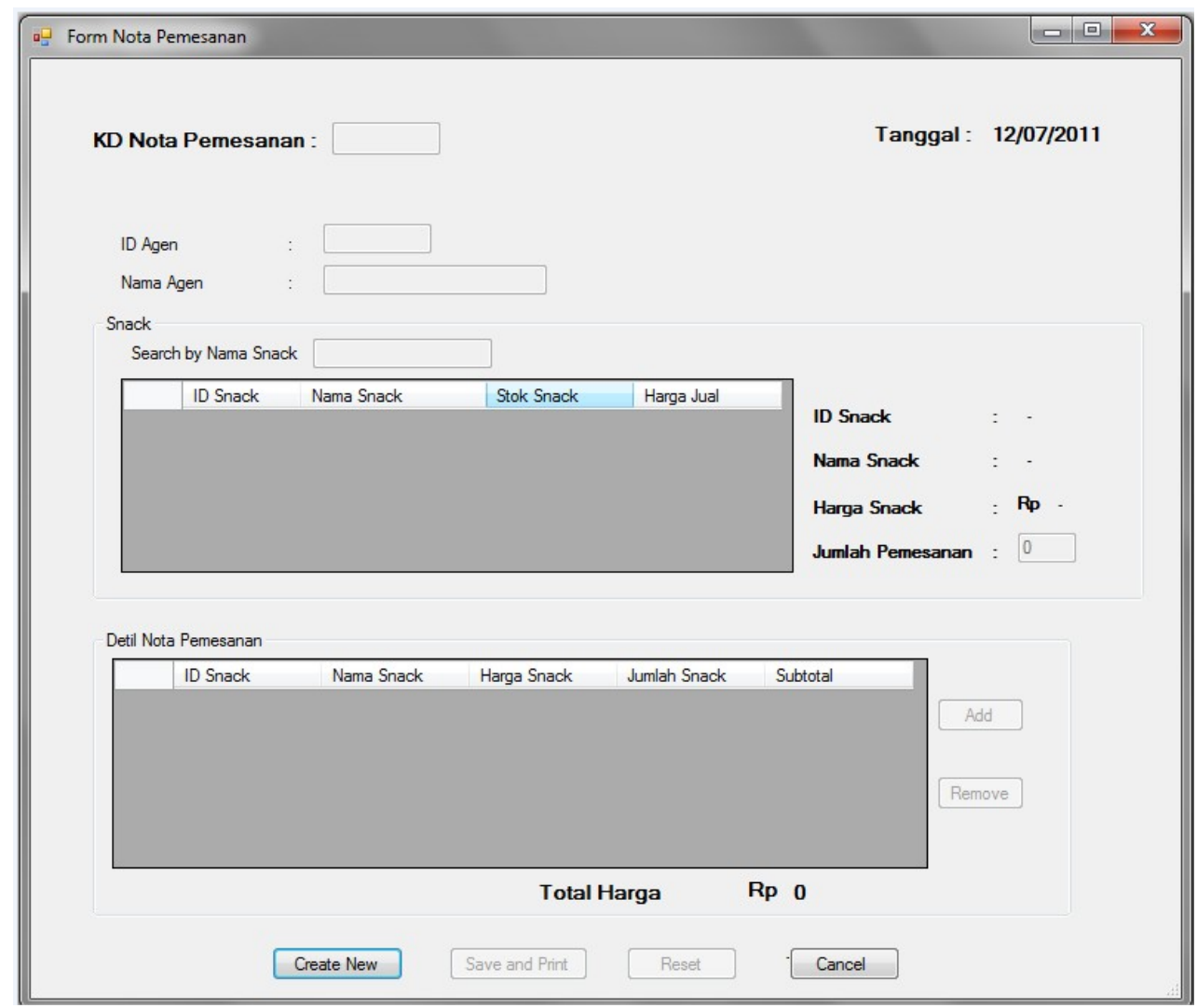

Gambar 5 Rancangan form nota pemesanan

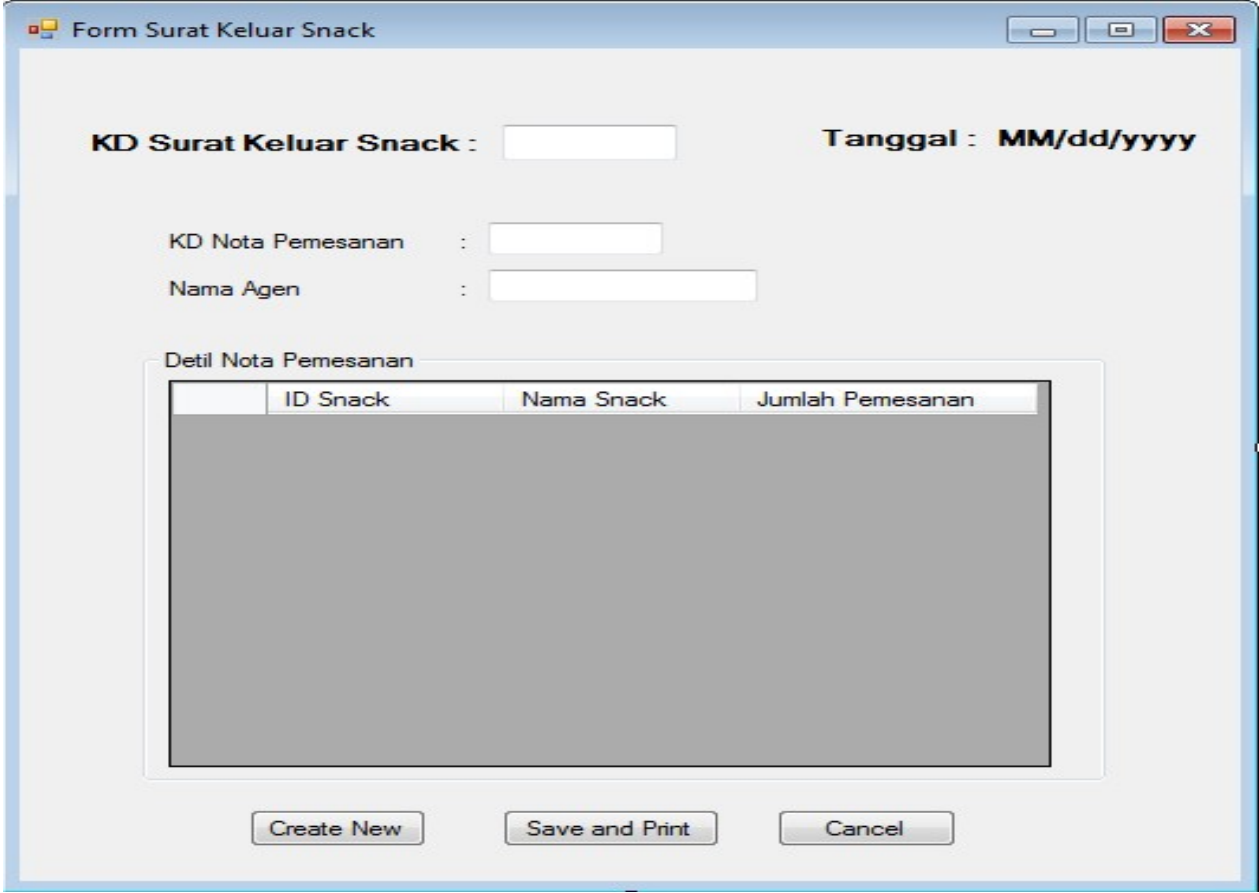

Gambar 6 Rancangan Form surat keluar snack 


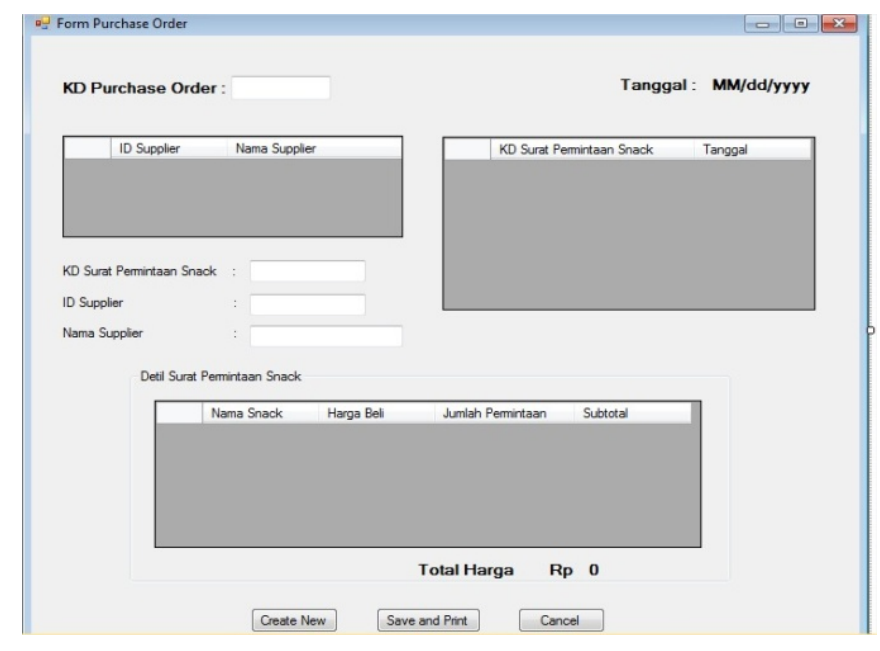

Gambar 7 Rancangan Form Purchase Order

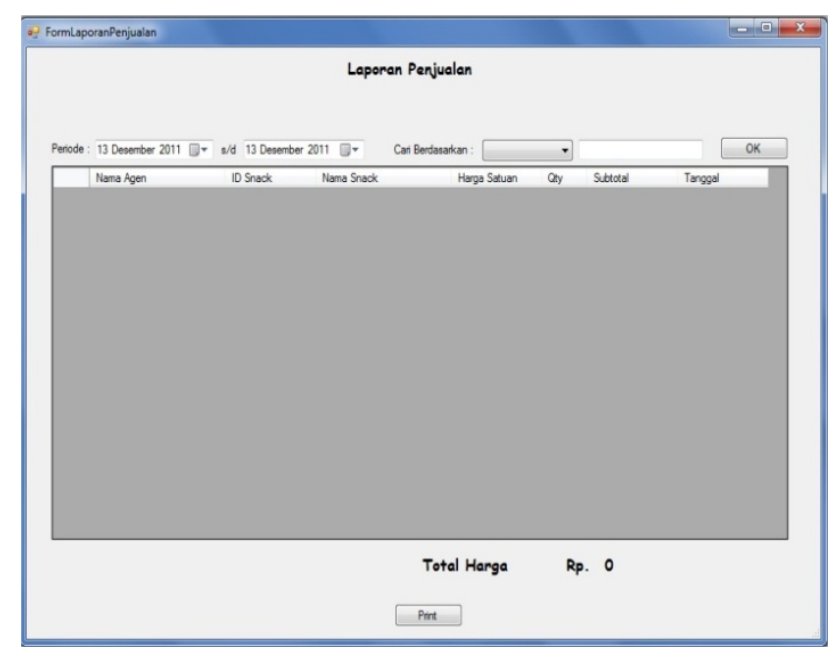

Gambar 8 Rancangan Form laporan penjualan

Berikut ini adalah Input integrity control yang akan diimplementasikan pada CV Bambi.

\section{Input Integrity Controls}

\section{Field Combination Controls}

Pada sistem yang di usulkan pada CV.Bambi terdapat field combination control yaitu integrity control yang memverifikasi data di suatu field dengan berdasarkan pada data yang berada di field lain. Contohnya, apabila bagian administrasi ingin membuat surat keluar snack kepada bagian gudang maka bagian administrasi membutuhkan data yang ada di nota pemesanan. Jadi ketika bagian administrasi membuat surat keluar snack maka data nota pemesanan akan muncul di form surat keluar snack.

\section{Value Limit Controls}

Value limit control adalah integrity control yang mengidentifikasi bahwa nilai yang dimasukkan pada field masuk akal. Contohnya, apabila persediaan snack yang ada di gudang tersisa 
500, bagian gudang harus membuat surat permintaan snack. Surat permintaan snack tidak bisa dibuat apabila jumlah snack yang berada digudang lebih dari 1000.

\section{Completeness Controls}

Completeness controls adalah integrity control yang memastikan bahwa semua field yang ada di suatu sudah terisi semua. Misalnya, saat pemilik ingin membuat data agen baru maka pemilik harus memasukkan nama, alamat, dan nomor telepon agen. Apabila salah satu field belum terisi maka ketika pemilik memilih tombol save maka akan keluar peringatan bahwa salah satu field belum terisi.

\section{Data Validation Controls}

Data validation control dilakukan dengan verifikasi field numerik yang berisi kode sudah diisi dengan benar. Contohnya, apabila bagian administrasi ingin login, Bagian administrasi harus memasukkan username dan password yang panjang nilainya sudah ditentukan dan sesuai dengan yang terdapat pada database.

\section{Database Intergrity Controls}

\section{Access Controls}

Integrity control yang membatasi siapa saja yang dapat mengakses sistem. Misalnya yang hanya dapat melihat, menghapus dan mengubah jumlah ketersediaan snack yang ada digudang adalah bagian gudang.

\section{Transaction Controls}

Teknik intergrity control yang apabila database di-upgrade akan dicatat sesuai misalnya dengan siapa yang melakukan update.

\section{Update Controls}

Update control adalah integrity control di mana apabila suatu form akan di upgrade, field yang dapat diubah hanya field selain dari primary key. Apabila ingin mengubah data agen, pemilik tidak dapat mengubah ID pemilik.

\section{Output Integrity Controls}

\section{Destination Controls}

Form satu dengan form yang lainnya saling terkait atau berhubungan dan ditujukan ke bagian tertentu. Misalnya bagian administrasi membuat surat permintaan barang ke bagian gudang dan field yang ada di di form surat permintaan barang sebagian berisi field yang ada di nota pemesanan.

\section{Completeness, Accuracy dan Correctness Control}

Setiap laporan yang dibuat oleh bagian administrasi dan bagian gudang di setiap bulannya akan tertera tanggal di hasil cetaknya dan akan diperjelas dengan ditambahkan bold.

Setiap bagain yang ada diperusahaan ingin melakukan transaksi harus melakukan login terlebih dahulu. Setiap bagian memiliki kode bagian masing-masing. Pembuatan kode khusus ditiap bagian dimaksudkan untuk meningkatkan keamanan data transaksi. 
User CV Bambi di dalam aplikasi dibagi menjadi tiga kategori, yaitu unauthorized user, registered user dan privileged use. Bagian pengiriman, agen dan supplier termasuk unauthorized user. Ketiganya tidak diperbolehkan untuk mengakses ke dalam sistem. Agen hanya dapat melakukan pemesanan melalui SMS, begitupun dengan supplier yang tidak bisa mengakses ke dalam sistem. Bagian pengiriman hanya mendapat tugas untuk mengirimkan pesanan dan tidak diperbolehkan untuk mengakses sistem. Registered user adalah orang yang dapat mengakses ke dalam sistem. Pemilik, bagian administrasi dan bagian gudang termasuk dalam kategori registered user. Ketiganya dapat mengakses ke dalam sistem untuk melakukan transaksi di bagian masing-masing. Privileged user dapat disebut juga sebagai programmer atau orang yang mengerti seluruh sistem komputerisasi dan keamanan data yang berjalan. Yang termasuk dalam privileged user adalah pemilik karena pemilik akan diberikan pelatihan untuk dapat mengakses program dan database yang ada di perusahaan. Bagian administrasi juga dapat dimasukkan ke dalam kategori ini karena bagian administrasi yang akan menjalankan banyak proses bisnis yang terjadi di dalam perusahaan.

\section{PENUTUP}

Dari penelitian ini dapat disimpulkan bahwa CV Bambi masih menggunakan proses secara manual pada proses bisnis penjualan, pembelian dan inventori. Pencatatan data penjualan, pembelian dan inventori yang dilakukan di kertas memungkinkan data tercecer dan hilang. Untuk membuat laporan penjualan, pembelian dan inventori harus dilakukan rekapitulasi yang menghabiskan waktu banyak seperti harus mengumpulkan semua nota pemesanan dari awal sampai akhir bulan. Hasil dari perancangan sistem informasi ini adalah sebuah sistem informasi yang dapat mengatasi masalah dalam pencarian data baik pada proses penjualan, pembelian ataupun inventori karena semua data telah terintegrasi satu dengan yang lainnya dan terupdate secara realtime. Melalui fitur reporting pada sistem akan mempermudah pemilik perusahaan untuk melihat laporan penjualan, pembelian dan inventori setiap bulannya tanpa perlu melakukan rekapitulasi transaksi-transaksi yang terjadi.

\section{DAFTAR PUSTAKA}

Forster, F., Brocco, M. (2008). Understanding Creativity-Technique Based Problem Solving Processes. 12th International Conference on Knowledge-Based Intelligent Information and Engineering Systems, 5178. New York: Heidelberg.

Markus, M. L., Majchrzak, A., \& Gasser, L. (2003). A Design Theory for Systems that Support Emergent Knowledge Processes. MIS Quarterly, 26, 179 - 212.

Mathiassen, L., Munk-Madsen,A., Nielsen, P.A., Stage, J. (2000). Object-Oriented Analysis \& Design. Denmark: Marko Publishing.

Peterson, D.K. \& Kim, C.S. (2000). Information system objectives: effects of experience, position level, and education on developers. Journal of Information Technology Management, 11 (3 4).

Rainer, R.K. \& Cegielski, C.G. (2011). Introduction to Information System. New Jersey: John Wiley \& Sons.

Satzinger, J W., Jackson, R.B, \& Burd, S.D. (2012). System Analysis and Design in a Changing World. Kentucky: Cengage Learning.

Whitten, J.R. \& Bentley, L.D. (2007). Systems Analysis and Design Method. New York: McGrawHill. 